\title{
Assessing the progress of desertification of the southern edge of Chihuahuan Desert: A case study of San Luis Potosi Plateau
}

\author{
NOYOLA-MEDRANO Cristina ${ }^{1}$, MARTÍNEZ-SÍAS Valeria Abigaíl ${ }^{2}$ \\ 1. Facultad de Ingeniería / Area Civil / Geoinformática /Universidad Autónoma de San Luis Potosí, Manuel \\ Nava \# 8, Zona Universitaria Poniente, 78290, San Luis Potosí, SLP, Mexico; \\ 2. Colegio de Posgraduados / Campus San Luis Potosí. Iturbide 73, Salinas de Hidalgo, SLP, Mexico
}

\begin{abstract}
The aim of this study is to establish if the San Luis Potosi Plateau (SLPP), which is part of the southern edge of the Chihuahuan Desert, is generating desertification processes, indicating a progression of the desert toward the central part of Mexico. Therefore, we analyzed the temporal evolution of four environmental indicators of desertification: Normalized Difference Vegetation Index (NDVI), Normalized Difference Water Index (NDWI), Iron Oxides Index (IO) and Surface Temperature (ST). Landsat TM images are used to cover a period from 1990 to 2011. A new equation of total balance is proposed to generate an image of the overall evolution of each factor which is applied to get a probability map of desertification. The evolution of NDVI, NDWI and IO shows a behavior almost stable over the time. In contrast, the ST shows a slight increase. The outcomes of this study confirm periods of vegetation re-greening and $8.80 \%$ of the SLPP has the highest probability to develop desertification. The most affected area is the portion west of the region, and the east and south are the least affected areas. The results suggest a slight advance of the desert, although most of the area doesn't have the necessary conditions to develop desertification.
\end{abstract}

Keywords: Landsat; NDVI-NDWI; ST-IO; desertification; re-greening vegetation

\section{Introduction}

Argue that a region is developing desertification processes has a significant impact on the planning of land management policies. For that reason, it's important to analyze if the region is showing signs of desertification. The clear identification of the causes and processes of desertification can be hindered by the interaction between natural and anthropic phenomena and, by confusion between the environmental cyclical oscillations of short term, with those representing long-term degradation (Xu et al., 2011; Granados-Sánchez et al., 2013).

The soil degradation occurs in whatever portion of the earth's surface, but it is fixed as

Received: 2016-03-18 Accepted: 2016-05-17

Foundation: Program for Professional Development of Professors (PRODEP) through the convention PROMEP/103.5/ $13 / 6575$

Author: Cristina Noyola-Medrano (1970-), specialized in natural resource and environmental remote sensing. E-mail: cristina.noyola@uaslp.mx 
"desertification" when it occurs in arid, semi-arid and sub-humid dry areas, derived from the human impact (Helldén, 1992; Reynolds et al., 2007). Desertification is not just a problem of soil loss, but it touches on the stability and development of human populations. Moreover, the effects of desertification affect not only the source but also very remote spots from the inception of the phenomenon (Tao, 2004).

The United Nations (UN) contends that desertification threatens the livelihoods of a billion people in over 100 countries spread over one-fourth of the earth's land surface. Africa is the most damaged continent by desertification, followed by Latin America, the Caribbean and Southern Europe (Ezcurra, 2006). In Mexico, the arid and semi-arid lands are chiefly in the deserts of Sonora, Chihuahua and the central regions influenced by the rain shadow effect caused by the Sierra Madre Occidental and Oriental (Pando-Moreno et al., 2002). Previous studies have reported $1,240,000 \mathrm{~km}^{2}$ of arid and semi-arid regions, which is equivalent to approximately $60 \%$ of the entire territory of Mexico (Díaz-Padilla et al., 2011). Despite the problem posed by desertification mechanisms, De Waroux and Lambin (2012) explain that the processes of degradation of arid and semi-arid lands have received little attention.

Based on this scenario, it is advisable to set up mechanisms to help evaluate whether the arid and semi-arid soils of Mexico have a mechanism of irreversible desertification. For this reason, it is equally important to determine the concept of cyclical swing vegetation which is largely linked to climatic fluctuations. The first work report of cyclical swing took place in the Sahara between 1980 and 1990 (Tucker et al., 1991). The results of this work show that there was an increase in the vegetation when it increased precipitation and that this period followed a prolonged dry spell between 1980 and 1984. Other studies were supported by the analysis of photographs, field work and implementation normalized index (NDVI), to demonstrate the reversibility of the coating degradation vegetation (Helldén, 1992).

Because of the importance of determining if a region is under a phenomenon of desertification or cyclic oscillation, several works supported by Geoinformatics techniques have been generated (Santini et al., 2010; Gamo et al., 2013). These studies include the role of satellite images and the implementation of Geographic Information Systems (GIS). In this way, Collado and others (2002) examined the phenomenon of desertification for the Province of San Luis (Central Argentina). They have applied the techniques as Spectral Mixture Analysis (SMA) and analysis of change from Landsat images. They concluded the area showed severe signs of degradation, although, in the zone there is vegetation recovering. Haboudane and others (2002) applied the analysis of indices generated from the spectrum shape to record that the optical properties of the soil surface can be utilized as indicators of degradation in semi-arid environments. Also, they set indices which integrate short-wave infrared bands to detect pedogenetic indicators that serve to characterize the degradation of soils with sparse vegetation. Another technique for detecting desertification applies standardized values of NDVI and precipitation (z-score) from NOAA AVHRR images. The outcomes of this survey concluded that the behavior of the vegetation seems to be at odds with the common view that the desertified areas are increasing worldwide (Helldén and Tottrup, 2008). However, these results have the problem of spatial resolution, which can mask the behavior-ground vegetation locally. Some sources have reported about the potential of using high-resolution satellite data such as Landsat TM to evaluate the desertification process and reversibility in degradation (Helldén and Tottrup, 2008; Ouedraogo et al., 2014). 
Several authors have treated the evaluation of desertification in Mexico, and each point indicates different factors that contribute to desertification processes, particularly in the northern and central part of Mexico. Among the studies produced along this topic, one of them has reported moisturizing as a critical ingredient for the assessment of desertification (Huber-Sannwald et al., 2006). The oxidation, resulting from desert varnish, is another important feature for assessing land degradation because some elements such as wind abrasion and human disturbance can completely remove the varnish, or disrupt its appearance greatly (Dorn, 1986). On the other hand, Becerril-Piña and others (2015) analyzed with Landsat imagery the phenomenon of desertification for the Central Mexican Plateau; pointing out that one of the most significant factors is the vegetation-soil relationship because it permits to show that desertification is closely linked to deforestation and land use change. Nevertheless, a study released in the Sonoran Desert, highlights the importance of the relationship among albedo, surface temperature, and NDVI, because these factors present a cyclical pattern, and it is observed an increase in apparent desertification surfaces in years with longer periods of radiation (Tereshchenko et al., 2012).

Considering the above, the aim of this paper is to identify if the SLPP, in the southern edge of the Chihuahuan Desert, is developing processes of desertification. For this purpose, it has been analyzed and integrated into a balance equation, four parameters considered as potential indicators of desertification processes: Vegetation Index (NDVI), Moisture Index (NDWI), Iron Oxides Index (IO) and Surface Temperature (ST). All the data to implement the indices is extracted directly from Landsat TM images and supplemented with information on rainfall and temperature from weather stations.

\section{Materials and methods}

\subsection{Study area}

SLPP is located in the Province of the Central Plateau, in the southern edge of the Chihuahuan Desert in Mexico. The area studied is located between $22^{\circ} 20^{\prime}-24^{\circ} 30^{\prime} \mathrm{N}$ and $100^{\circ} 25^{\prime}-$ $102^{\circ} 18^{\prime} \mathrm{W}$ (Figure 1) with a total area of $29,100 \mathrm{~km}^{2}$ (INEGI, 2012). Altitude values in this region vary from 1570 to $2680 \mathrm{~m}$ a.s.1.

The climate of the region is classified as dry steppe (BS) in the Köppen system, with the variants $\mathrm{BS}_{0}$ (the driest) and $\mathrm{BS}_{1}$ (the least dry). Precipitation is scarce and irregular, with an annual average from 240 to $770 \mathrm{~mm}$ and, the average annual temperature varies from $13.5^{\circ} \mathrm{C}$ to $20.5^{\circ} \mathrm{C}$ (INEGI, 2012). Common plant communities in the study area are the microphyllus desert scrub, rosetophilous scrub, crasicaule scrub, and thorny scrub patches (Hernández et al., 2001). Between urban and suburban vegetation, there are native species (Prosopis laevigata, Opuntia spp., Agave lechuguilla, Yuca filifera, Sabal mexicana and Quercus spp.), and introduced species (Eucalyptus camaldulensis, Casuarina equisetifolia, Ficus spp., Populus fremontii, Salix babylonica, Pinus spp., Schinus molle and Ligustrum japonicum), as well as vegetation related to irrigation and rain-fed crop areas (Galindo and García, 1986).

\subsection{Methodology}

The methodology to extract the areas with the greatest possibility of developing desertifica- 
tion is based on the analysis of the spatial-temporal variability of four factors: Normalized Difference Vegetation Index (NDVI), Normalized Difference Water Index (NDWI), Iron Oxides Index (IO) and Surface Temperature (ST) (Figure 2).

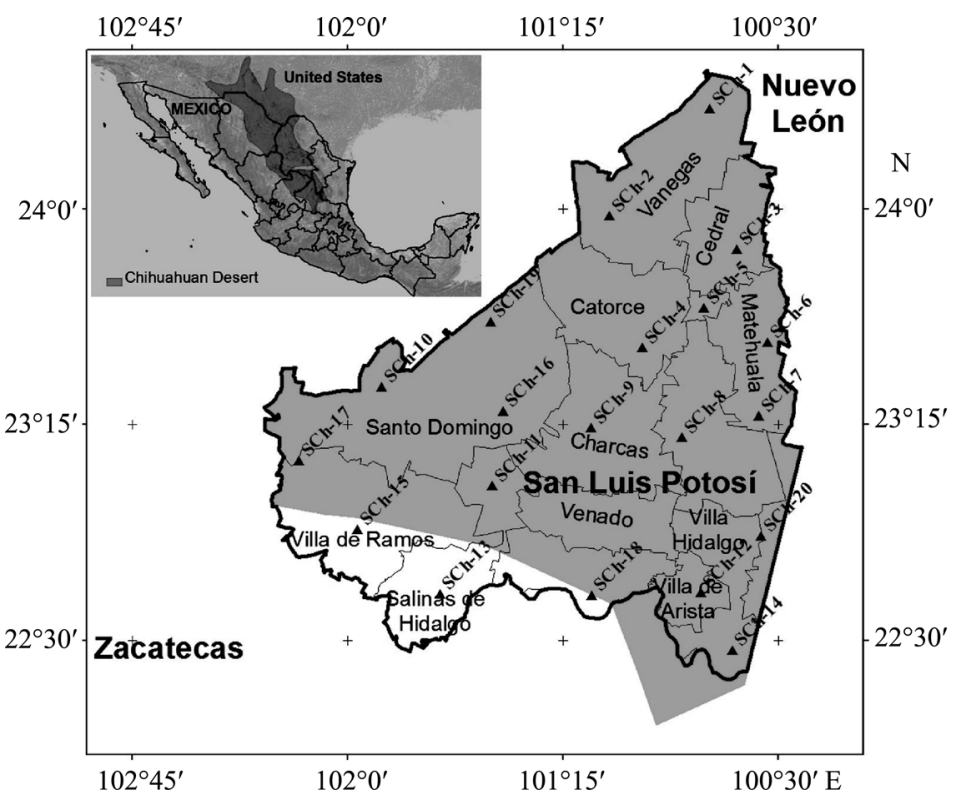

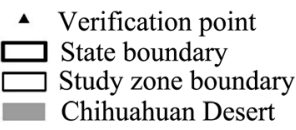

Transverse Mercator Projection

UTM Zone.13

$1 \mathrm{~cm}=11 \mathrm{~km}$

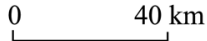

Figure 1 Location map of the region surveyed

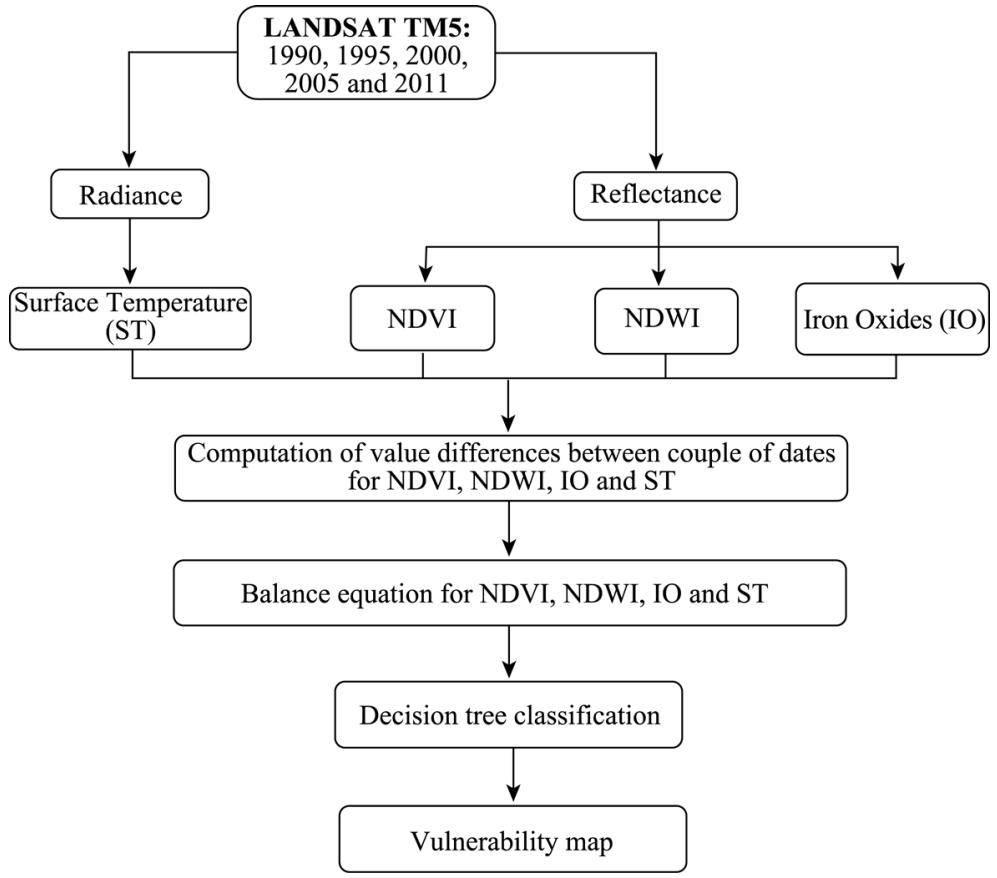

Figure 2 Methodology implemented in this work

2.2.1 Obtaining satellite images

For this work, Landsat TM5 images for the years 1990, 1995, 2000, 2005 and 2011 were 
Table 1 List of images used in this study

\begin{tabular}{cccccc}
\hline IMAGE & DATE & IMAGE & DATE & IMAGE & DATE \\
\hline LT5028043 & $03-16-1990$ & LT5028044 & $03-16-1990$ & LT5029044 & $03-07-1990$ \\
LT5028043 & $04-15-1995$ & LT5028044 & $04-15-1995$ & LT5029044 & $04-22-1995$ \\
LT5028043 & $03-11-2000$ & LT5028044 & $03-11-2000$ & LT5029044 & $04-19-2000$ \\
LT5028043 & $03-09-2005$ & LT5028044 & $03-09-2005$ & LT5029044 & $02-28-2005$ \\
LT5028043 & $04-27-2011$ & LT5028044 & $04-27-2011$ & LT5029044 & $04-02-2011$ \\
\hline
\end{tabular}

used (Table 1). All the images were selected for the dry season (January to April). The images have been obtained by the GLOVIS server, managed by the USGS (United States Geological Survey). ENVI 4.7 is used for the treatment of images, and the final integration of the maps is made in ArcGIS 10.2.

\subsubsection{Radiometric correction}

The first step consists of converting the digital number values to radiance values for all bands, including the band 6 (thermal). For this purpose, it uses ENVI 4.7 software, which applies the equation suggested by Chander and others (2009) (Equation 1):

$$
L_{\lambda}=\text { Grescale } \times \text { Qcal }+ \text { Brescale }
$$

where $L_{\lambda}$ is spectral radiance at the sensor's aperture $\left[\mathrm{W} /\left(\mathrm{m}^{2} \cdot \mathrm{sr} \cdot \mu \mathrm{m}\right)\right]$, Grescale is band-specific rescaling gain factor $\left[\left(\mathrm{W} /\left(\mathrm{m}^{2} \mathrm{sr} \mu \mathrm{m}\right)\right) / \mathrm{DN}\right]$, and Brescale is band-specific rescaling bias factor $\left[\mathrm{W} /\left(\mathrm{m}^{2} \mathrm{sr} \mu \mathrm{m}\right)\right]$

The computation of the reflectance is generated for the bands 1, 2, 3, 4, 5, and 7. Likewise, for this process, it uses ENVI 4.7 based on the equation suggested by Chander and others (2009) (Equation 2):

$$
\rho \lambda=\frac{\pi L_{\lambda} d^{2}}{E S U N_{\lambda} \sin \theta}
$$

where $\rho_{\lambda}$ is radiance in units of $\mathrm{W} /\left(\mathrm{m}^{2} \cdot \mathrm{sr} \cdot \mu \mathrm{m}\right), d$ is earth-sun distance in astronomical units, $\operatorname{ESUN}_{\lambda}$ is solar irradiance in units of $\mathrm{W} /\left(\mathrm{m}^{2} \cdot \mu \mathrm{m}\right)$, and $\theta$ is sun elevation in degrees.

\subsubsection{Surface temperature (ST)}

To calculate the surface temperature (ST), the values of the radiance of band 6 were used to work the algorithm of Emissivity Normalization of ENVI 4.7. This algorithm generates values of ST in Kelvin (K). Immediately, $K$ values were converted into Celsius Degrees $\left({ }^{\circ} \mathrm{C}\right)$. The algorithm for the ST (Eq. 3) is based on the proposal of Chander and others (2009).

$$
S T=\frac{K_{2}}{\ln \left(K_{1} / L_{\lambda}+1\right)}
$$

where $S T$ is brightness temperature of sensor (Kelvin), $K_{2}$ is calibration constant 2 in Kelvin (1260.56), $K_{1}$ is calibration constant 1 in $\left[\mathrm{W} /\left(\mathrm{m}^{2} \mathrm{sr} \mu \mathrm{m}\right)\right]$ (607.76), ln is natural logarithm.

\subsubsection{Normalized Difference Vegetation Index (NDVI) calculation}

NDVI permits to find out if the vegetation is healthy, with some grade of stressor simply there is no vegetation cover (Huete et al., 2002). The algorithm of the vegetation index is generated based on the values of reflectivity. This index works with data located in the 
wavelengths from $0.66 \mu \mathrm{m}$ (Red) to $0.86 \mu \mathrm{m}$ (NIR), because in the red region, it is observed a strong absorption by the presence of pigments such as chlorophyll, whereas the NIR region presents high reflectances related to the structure of the plant.In order to obtain the NDVI index, it uses Equation 4:

$$
N D V I=\frac{\rho_{N I R}-\rho_{R E D}}{\rho_{N I R}+\rho_{R E D}}
$$

where $\rho_{\text {NIR }}$ is $0.77-0.90 \mu \mathrm{m}$, which corresponds to band 4 of Landsat TM, and $\rho_{R E D}$ is $0.63-0.69 \mu \mathrm{m}$, which corresponds to band 3 of Landsat TM

The results of calculations of NDVI for a given pixel have always ranged from -1 to +1 . Zero means no vegetation and the values close to $+1(0.8-0.9)$ indicate the presence of green and abundant foliage.

\subsubsection{Iron Oxides Index (IO)}

This band ratio highlights hydrothermally altered rocks or weathering soils that have been subjected to oxidation of iron (Drury, 1987). In this study, the IO is applied (Eq.5) because in the semi-desert areas it is common that soils developed desert varnish, which it can be detected with high values of IO. This rock rust or desert patina forms only on physically stable soil surfaces that are no longer subject to frequent precipitation, fracturing, wind abrasion or some other removal process (Spatz et al., 1989; Ustin et al., 2009). Consequently, zones with low values of IO are considered areas with soils degraded.

$$
O I=\frac{\rho_{\mathrm{RED}}}{\rho_{\mathrm{BLUE}}}
$$

where $O I$ is iron oxide index, $\rho_{\text {RED }}$ is $0.63-0.69 \mu \mathrm{m}$, corresponds to band 3 of Landsat TM, and $\rho_{\text {BLUE }}$ is $0.45-0.52 \mu \mathrm{m}$, which corresponds to band 1 of Landsat TM

\subsubsection{Normalized Difference Water Index (NDWI)}

The moisture content is an indicator of the relationship between precipitation and potential evapotranspiration as a manifestation of water demand exerted by the surroundings. According to Gao (1996) NDWI is defined as:

$$
N D W I=\frac{\rho_{\mathrm{NIR}}-\rho_{\mathrm{SWIR}}}{\rho_{\mathrm{NIR}}+\rho_{\mathrm{SWIR}}}
$$

where $\rho_{\mathrm{NIR}}$ is $0.77-0.90 \mu \mathrm{m}$ (Band 4 of Landsat TM), and $\rho_{\mathrm{SWIR}}$ is $1.56-1.78 \mu \mathrm{m}$ (Band 5 of Landsat TM)

This band ratio is capable of detecting moisture because, in wetlands, the NIR region shows the maximum reflectivity and the SWIR zone shows the maximum absorption (Gao, 1996).

\subsubsection{Temporal differences}

From every factor obtained, there have been created maps of change to know temporary differences. To get this product, a simple subtraction is executed between a pair of images from different dates (Equation 7).

$$
\text { Dif } f_{x f}=f_{t 1}-f_{t 2}
$$

where $D i f_{x f}$ is differences of $x$ factor (NDVI, NDWI, ST, IO), $f_{t 1}$ is value of $x$ factor in time 1 
(oldest date), and $f_{t 2}$ is value of $x$ factor in time 2 (newest date).

At this stage, four images were obtained for every factor, called as difference images. In all of the cases, the analysis is made pixel-to-pixel, and it is considered a positive result when there is a decrease in value between the date 1 (oldest date) and the date 2 (newest date). Otherwise, a negative result meant that there is an increase in value between the two epochs.

\subsubsection{Computing balance equation}

It is common to analyze temporal changes based on comparisons of two different dates to estimate the rate of change. In this way, for analysis that takes more than two periods, it is necessary to obtain several rates of change for every pair of images. This approach can only take a partial survey of the phenomenon. Nevertheless, to get a perspective more balanced changes generated in the region, this work proposes a new balance equation from four images of changes of every factor obtaining in the previous step (Equation 8).

$$
B_{x f}=\sum_{i=1}^{n}\left(f_{t 1}-f_{t 2}\right)
$$

where $B_{x f}$ is image of final balance of " $x$ " factor (NDVI, NDWI, ST, IO), and $\left(f_{t 1}-f_{t 2}\right)$ denotes difference of " $x$ " factor for each couple of dates analyzed.

Positive or negative values were obtained for every pixel. In the case of NDVI, NDWI, and IO factors, a positive value indicates a greater risk of degradation of soils, because it involves loss of vegetation, moisture or desert varnish. In contrast, for ST, a negative value indicates an increase in temperature, which would raise the risk of development of desertification processes.

\subsubsection{Desertification vulnerability map}

The analysis of the probability to desertification was performed using the images of the final balance of every factor to develop a classification by a decision tree. For this classification, the NDVI is established as a most important factor to explain the desertification, followed by NDWI, ST, and OI

Table 2 Thresholds considered establishing the map of probability to desertification

\begin{tabular}{lc}
\hline Factor & Threshold \\
\hline NDVI & $>0.3$ \\
NDWI & $>0.3$ \\
ST & $<-3^{\circ} \mathrm{C}$ \\
IO & $>0.5$ \\
\hline
\end{tabular}
(Table 2). The level of significance is set based on previous works on desertification (PandoMoreno et al., 2002; Oyama and Nobre, 2004; Ustin et al., 2009).

\subsubsection{Validation of the map of desertification probability}

The verification of the final map of desertification probabilities was done based on accurate observations on 20 sites visited between the months of March and April of 2011.

The observation schedule was from 8 a.m. to $12 \mathrm{p} . \mathrm{m}$. of a day. The covering of green vegetation, desiccation cracks, and desert varnish layer was obtained using a proportional value from the total area of a square of $1 \mathrm{~m} * 1 \mathrm{~m}$. The surface temperature was measured with a thermometer, and the value of the amount of moisture was estimated from the parameters established by USDA-NRCS (1998). The level of probability of desertification was established according to the criteria of Table 3. 
Table 3 Parameters used to perform field verification

\begin{tabular}{cccccc}
\hline $\begin{array}{c}\text { Green } \\
\text { vegetation (\%) }\end{array}$ & Moisture $(\%)$ & $\begin{array}{c}\text { Surface } \\
\text { temperature }\left({ }^{\circ} \mathrm{C}\right)\end{array}$ & $\begin{array}{c}\text { Desert } \\
\text { varnish }(\%)\end{array}$ & $\begin{array}{c}\text { Desiccation } \\
\text { cracks }(\%)\end{array}$ & $\begin{array}{c}\text { Desertification } \\
\text { probability }\end{array}$ \\
\hline$>80$ & $>40$ & $<20$ & $>50$ & 0 & Very low \\
$60-80$ & $30-40$ & $20-22.5$ & $40-50$ & 0 & Low \\
$40-60$ & $20-30$ & $22.5-25$ & $30-40$ & $0-10$ & Moderate \\
$20-40$ & $10-20$ & $25-27.5$ & $20-30$ & $10-20$ & High \\
$<20$ & $<10$ & $>27.5$ & $<20$ & $>20$ & Very high \\
\hline
\end{tabular}

\section{Results and discussion}

\subsection{Observed changes in NDVI, ST, IO and NDWI}

This segment indicates the changes noted for every factor among the different dates analyzed. In the case of the NDVI, it is remarkable the great decrease between 2000 and 2005 (Figure 3c). Nevertheless, for the range of 2005-2011, it is observed stability and slightly recovering in the values of NDVI in the bigger portion of the region (Figure 3d). In the rest of the analyzed dates, moderate decreases of NDVI are presented throughout the area, and some areas show high and moderate increases, especially, in the eastern and southern portions (Figures $3 \mathrm{a}$ and $3 \mathrm{~b}$ ).

The outcomes of the NDWI analysis allow observing decreases in moisture between the ranges 1990-1995 and 2000-2005 (Figures 4a and 4c). In contrast, the ranges 1995-2000 and 2005-2011 showed increases of moisture in most of the region (Figures $4 \mathrm{~b}$ and $4 \mathrm{~d}$ ).
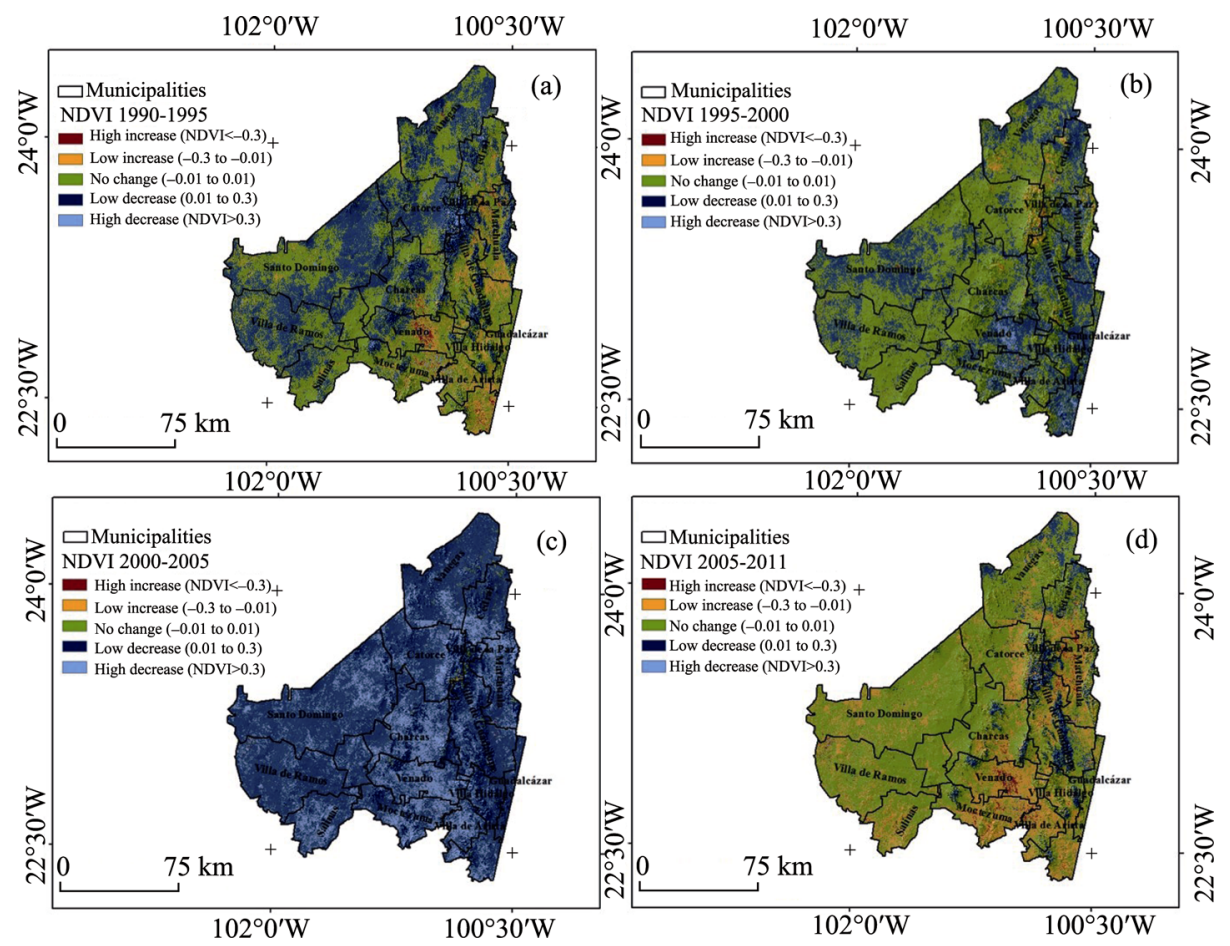

Figure 3 Maps showing changes in NDVI for a couple of dates: a) 1990-1995; b) 1995-2000; c) 2000-2005; d) 2005-2011 

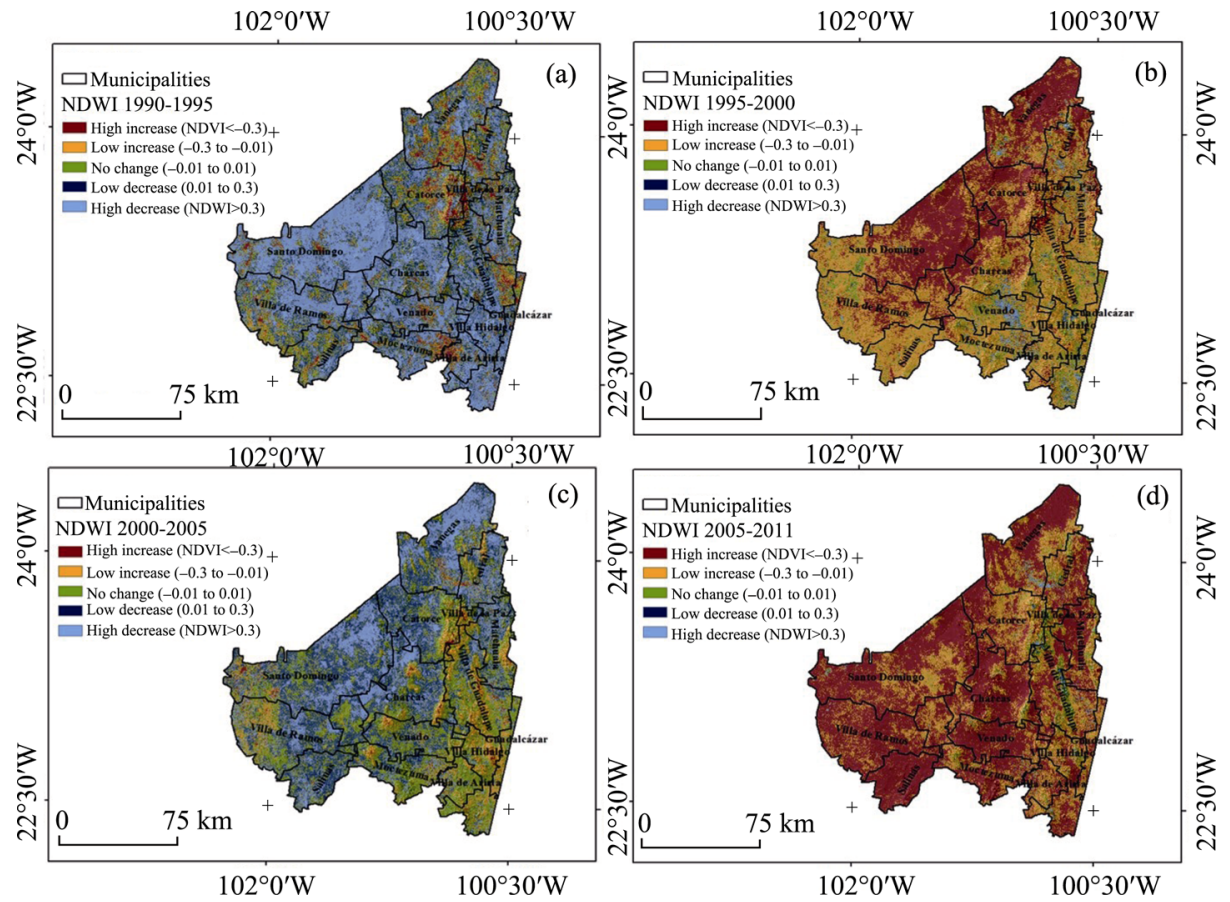

Figure 4 Maps showing the changes of NDWI for a couple of years: a) 1990-1995; b) 1995-2000; c) 20002005; d) 2005-2011

The dynamics of ST show for the first couple of dates (1990-1995) a high increase in the greater part of the region (Figure 5a). Between 1995 and 2000 a low decrease of ST appears
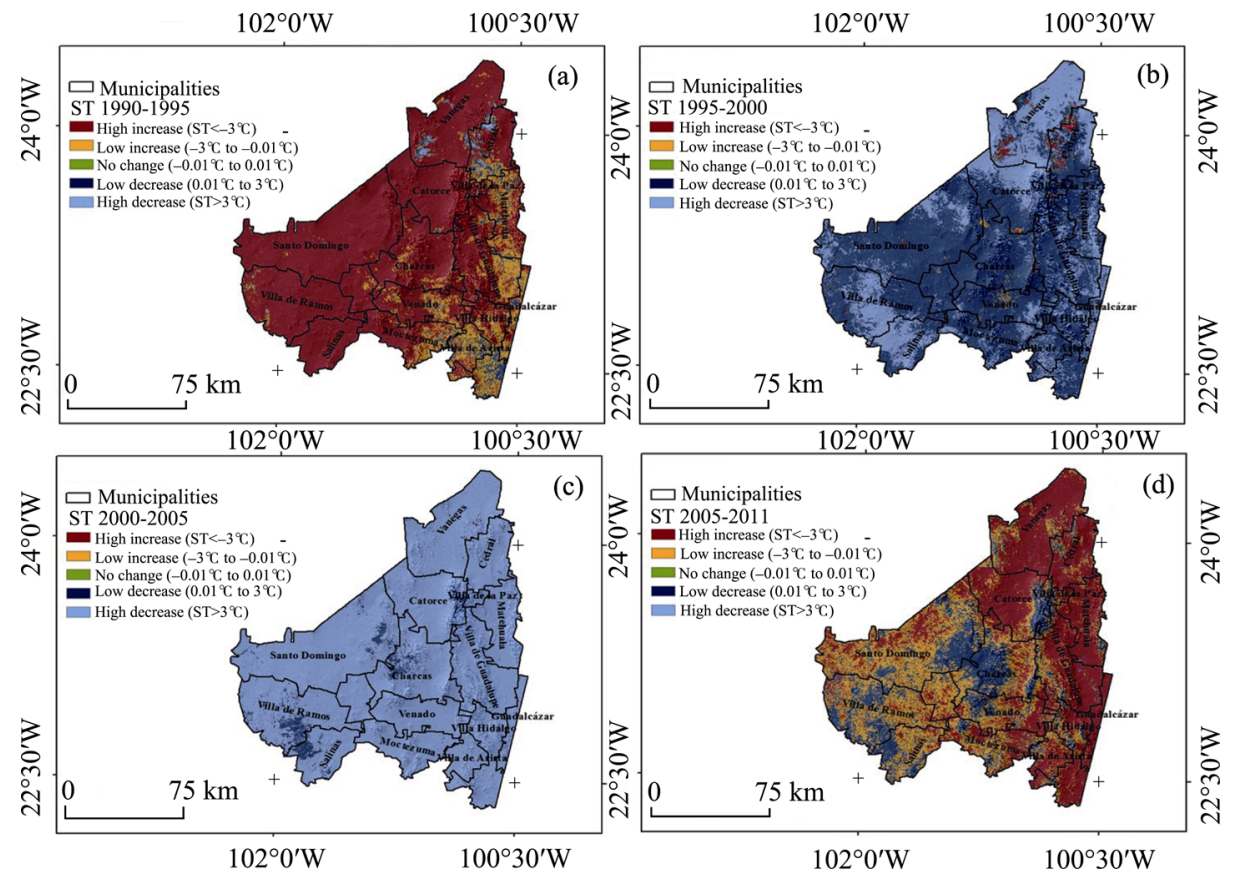

Figure 5 Maps showing changes of ST for a couple of dates: a) 1990-1995; b) 1995-2000; c) 2000-2005; d) 2005-2011 
in the entire study area, except for small areas which present high and moderate increase (Figure 5b). Between the years 2000 and 2005 there is a modest decrease in most of the region and to the Central and Southern portion, the reduction of ST is low (Figure 5c). The high increases in ST for the whole region returns to occur between 2005 and 2011 (Figure 5d).

The analysis of change for IO produced the following results: For the first time range (1990-1995), a lower increase of IO is observed in the entire study area, and a stable state of IO is in the south of the study area (Figure 6a). Between 1995 and 2000, the whole area remains stable values of IO (Figure 6b). However, between 2000 and 2005 there are small zones with little decrements of IO (Figure 6c) and, for the last time range (2005-2011), high and low increments of IO are again observed in the entire study area (Figure 6d).

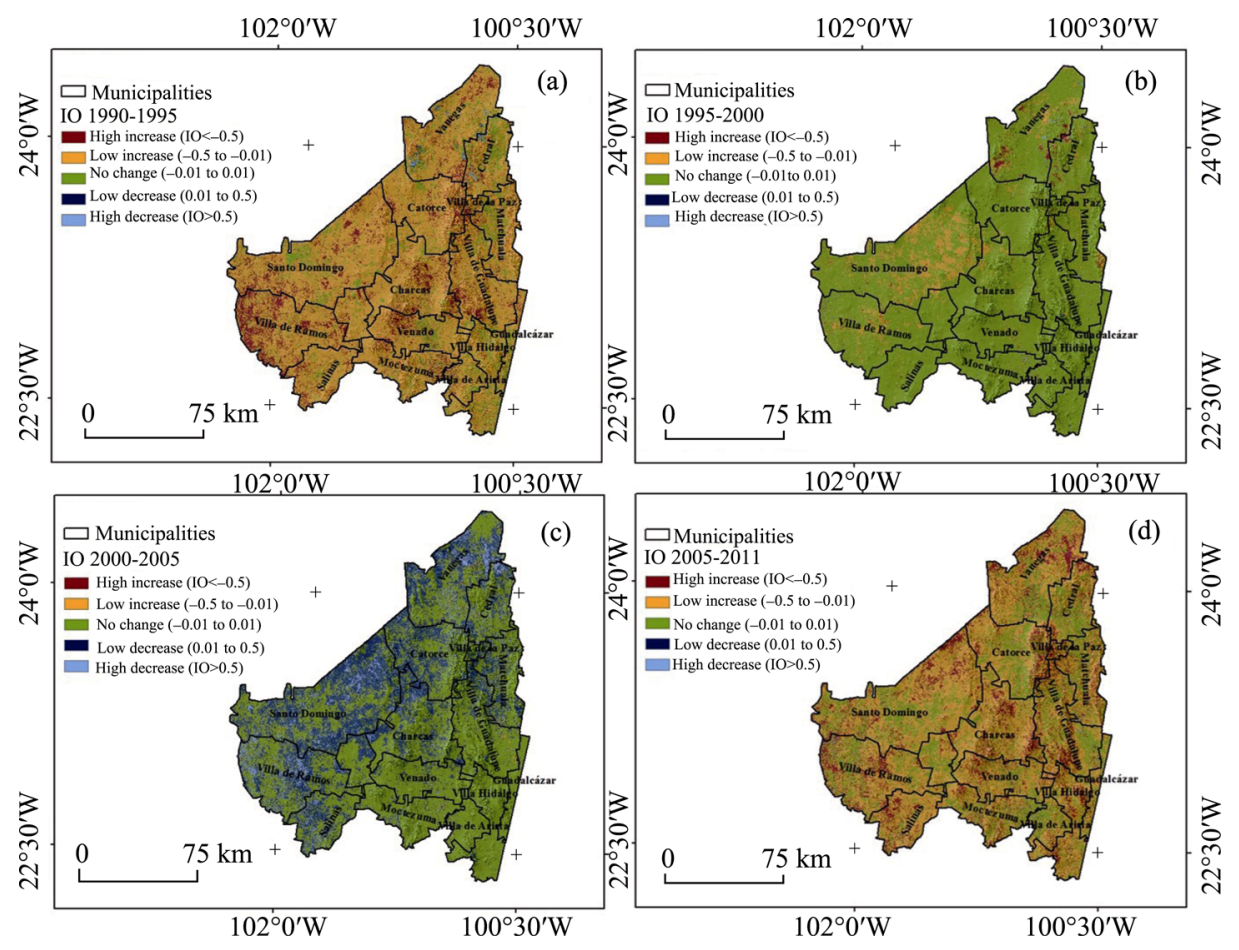

Figure 6 Maps showing the change of IO for a couple of years: a) 1990-1995; b) 1995-2000; c) 2000-2005; d) 2005-2011

The results do not allow establish a clear trend of steady decrease for NDVI, NDWI, and IO, or a constant increase of ST. This kind of behavior would be expected for a zone that is developing processes of desertification (Dorn, 1986; Collado et al., 2002; Ustin, 2009; Díaz-Padilla et al., 2011). Rather, the behavior in all factors is fluctuating, so there are dates with significant increases, followed by periods of time where the values of the factors decrease. For this reason, it is necessary to obtain the final balance of the behavior of each parameter, to get an overview more realistic of the changes generated in the study area.

The final balance of NDVI permits to verify decreases greater than 0.3 in the West-Central and North of the study zone (blue color; Figure 7a), involving mainly the municipalities of Santo Domingo, Vanegas and some offices of Real de Catorce, Charcas, and Guadalcazar. The rest of the zone remains stable in the values of NDVI (green color; Figure 7a). 


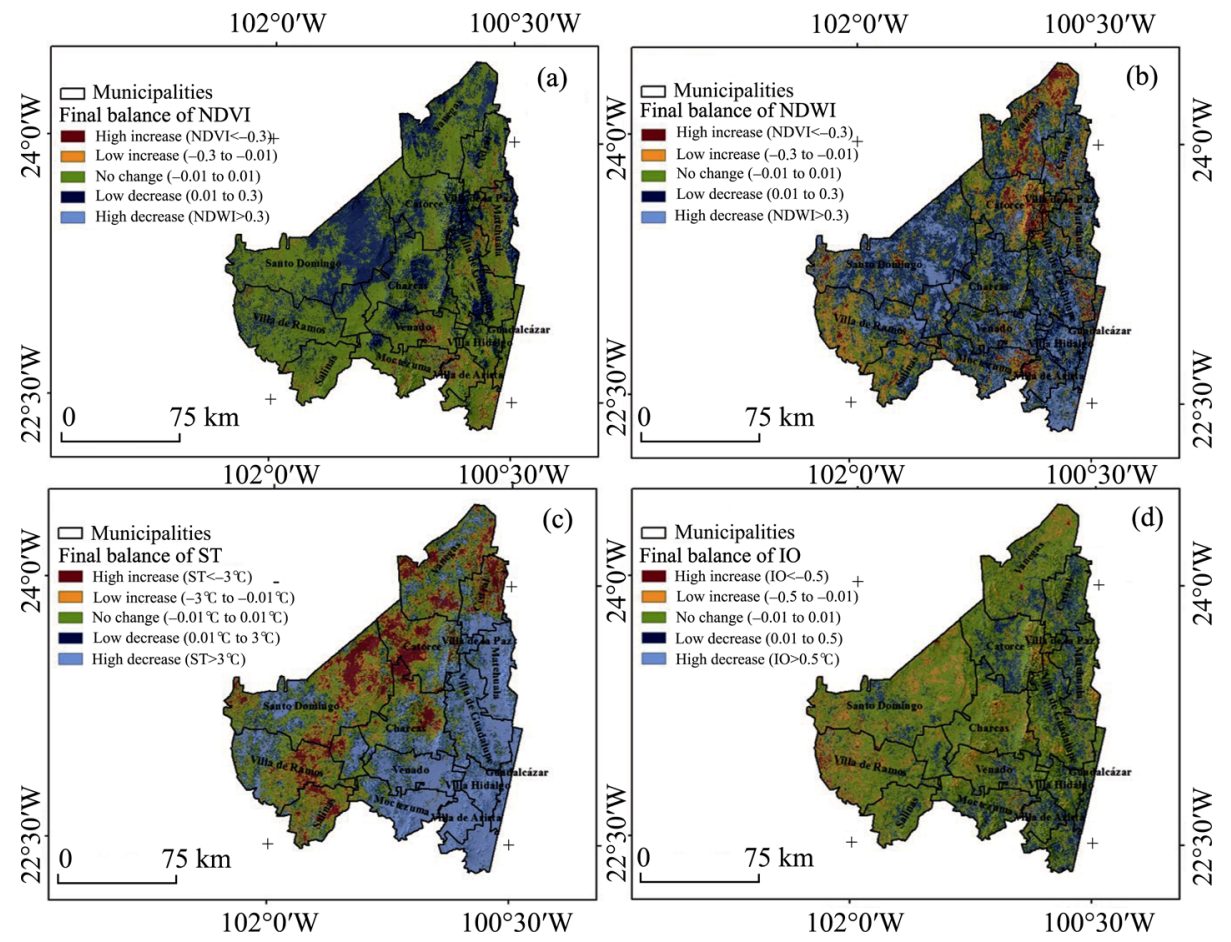

Figure 7 Maps of total balance for a) NDVI; b) NDWI; c) ST; d) IO

The overall balance of NDWI allows discovering different levels of decrease in this parameter across the area (Figure 7b). In some areas, although the NDWI decrease is high, the vegetation is retained which indicates the presence of vegetation with low levels of humidity. This characteristic is common in the vegetation of the desert (Huber-Sannwald et al., 2006). The municipalities most affected by decreasing moisture are Santo Domingo, Villa de Ramos, Charcas, Venado, Villa de Guadalupe and Villa Hidalgo (blue color; Figure 7b).

The map of the total balance of ST shows that the area most affected by high increases of temperature is the western portion of the SLPP, where it is registered rises above $3^{\circ} \mathrm{C}$ (red color; Figure 7c). The municipalities most affected by high increases in temperature are Santo Domingo, Villa de Ramos, Salinas, Catorce, Vanegas, Matehuala, and Cedral. In contrast, the eastern and southern parts have high decreases in ST (light blue; Figure 7c).

The total balance of IO shows a status of stability for the most of the SLPP (Green color; Figure 7d). This outcome corroborates the non-removal of the layer of desert varnish for the most of the region and, only in some parts this layer decreases slightly. However, there are some municipalities affected by slight declines in IO, such as Santo Domingo, Real de Catorce, Cedral, Matehuala, Villa de Guadalupe, Guadalcázar and Villa de Arista (blue color; Figure $7 \mathrm{~d}$ ). This effect is logical because these municipalities have an important farming and mining activity, which eases the removal of desert varnish.

\subsection{Potential areas to develop desertification in semi-arid environments}

Just parts of the region show adverse changes in some of the images of the final balance. However, with the purpose of establishing a more objective view of the phenomena of de- 


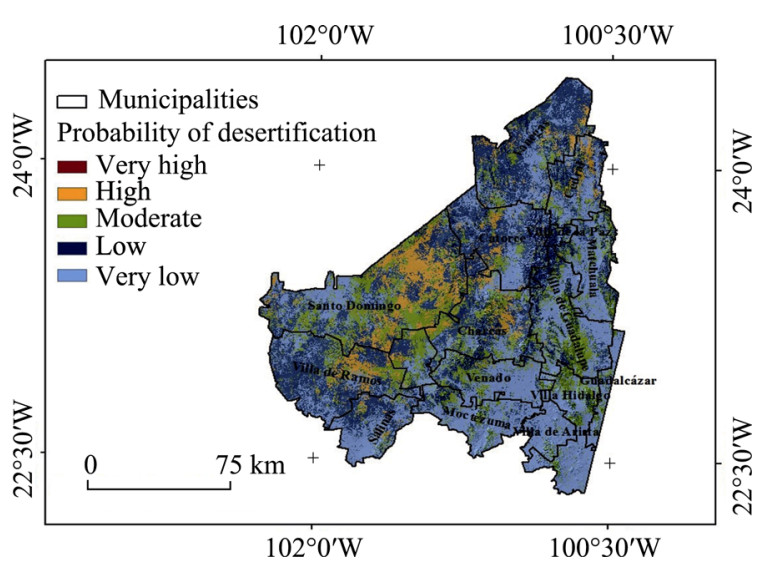

Figure 8 Map showing the areas with the highest probability of developing processes of desertification in the SLPP.

sertification in the region, a map of probabilities of desertification was produced based on the four images of the final balance. The resulting map shows small possibilities to develop processes of desertification in most of the field (blue color in Figure 8). Only some parts are more susceptible to problems of desertification (red color in Figure 8) because they demonstrate substantial decreases of NDVI, NDWI (decrease $>0.3$ ), IO (decrease $>0.5$ ) and significant increases for ST (increase $<-3^{\circ} \mathrm{C}$; Figure 7). In the field verification, the zones with very high desertification probabilities present values greater than $20 \%$ of the surface occupied by desiccation cracks. Vegetation is practically nonexistent; the ground temperature is above $28^{\circ} \mathrm{C}$ and the soil is dry (Figure 9e). The area covered by this level is $0.2 \%$, and the most affected municipality is Santo Domingo (Figure 8 and Table 4).

Following, is the area with a high potential for desertification which occupies an area of $8.78 \%$ (Table 4). This stage shows the slight presence of vegetation. The desiccation cracks occupy $10 \%-20 \%$ of the soil surface, the increase of ST varies between $-0.1^{\circ} \mathrm{C}$ and $-3^{\circ} \mathrm{C}$. NDVI and NDWI have decreases ranging between 0.01 and 0.3 and IO declines between 0.01 and 0.5 (Figure 7). On the ground, a limited coverage of desert varnish is observed with a ground temperatures of $25^{\circ} \mathrm{C}$ (Figure 9d). The municipalities most affected are Santo Domingo, Villa de Ramos, Real de Catorce, Salinas de Hidalgo, and Charcas (Figure 8).

In contrast, areas with very small possibility of desertification show a substantial coverage of green vegetation, ground temperatures less than $20^{\circ} \mathrm{C}$, high levels of moisture and the desiccation cracks are non-existent (Figure 9a). This level of probability occupies the largest area of the region (37.34\%; Table 4). In this case, the final balance of NDVI and NDWI show the highest increases $(<-0.3)$, IO also shows significant increases $(<-0.5)$ and ST presents the largest decreases $\left(>3^{\circ} \mathrm{C}\right.$; Figure 7$)$. The moderate level of desertification occupies $18.63 \%$ of the total area (Table 4 and Figure 8 ). In field verification, this level is characterized by patches of green and woody vegetation. The range of ground temperature is between $22.5^{\circ} \mathrm{C}$ and $25^{\circ} \mathrm{C}$. The coverage of desert varnish is variable, and few desiccation cracks are observed (Figure 9c). In this level, the final balance shows very slight variations in NDVI, NDWI, IO and ST (between -0.01 to 0.01; Figure 7).

The level of low probability is also widespread in the study area $(35.23 \%$; Table 4 and Figure 8 ). The zones that correspond to this level have ample coverage of woody vegetation, the desert varnish is well developed, the ground temperatures range between $20^{\circ} \mathrm{C}$ and $22.5^{\circ} \mathrm{C}$, and there are no desiccation cracks on the ground (Figure 9b). NDVI, NDWI, and IO show increase in the final balance ( -0.01 to -0.3 for NDVI and NDWI; -0.01 to -0.5 for IO). ST presents decreases, which varies between $0.01{ }^{\circ} \mathrm{C}$ to $3^{\circ} \mathrm{C}$ (Figure 7). 


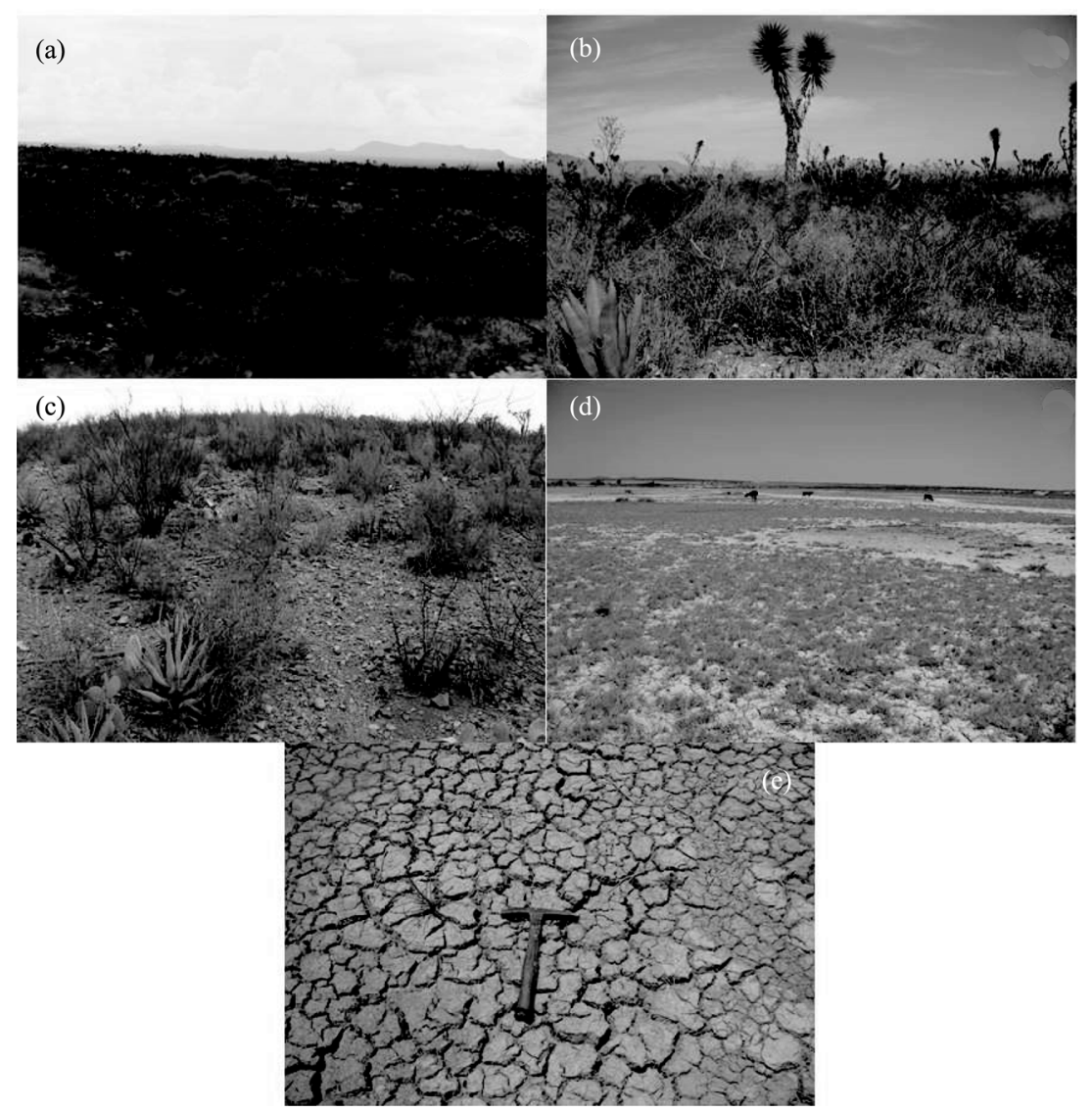

Figure 9 Landscapes related to different stages of desertification probability: a) Very low (point SCh-3), b) Low (point Sch-12), c) Moderate (point Sch-9), d) High (point Sch-19) and e) Very high (point Sch-16). The pictures were acquired during the field verification.

The field validation confirms an accuracy of $85 \%$ between field observations and the estimated data (Table 5). Therefore, these outcomes suggest that if each factor is analyzed on an individual basis, it could be concluded that almost the whole region is susceptible to a high level of desertification. However, the combination of all factors allows establishing a more balanced scene of the real status of the study zone concerning the hazard of generating desertification.
Table 4 Surface affected by the level of probability of developing desertification

\begin{tabular}{crc}
\hline Probability of desertification & Surface $\left(\mathrm{km}^{2}\right)$ & Surface $(\%)$ \\
\hline Very high & 1.20 & 0.02 \\
High & 2154.39 & 8.78 \\
Moderate & 4568.39 & 18.63 \\
Low & 8637.56 & 35.23 \\
Very low & 9154.67 & 37.34 \\
Total & 24516.21 & 100.00 \\
\hline
\end{tabular}

\subsection{Discussion}

The final result of this analysis can be explained according to climatic oscillations. For example, NDVI values from the year 2000 show a decrease related to precipitation values reported by the National Weather Service from Mexico (Figure 10a). This relationship between rainfall and greening or decrease in vegetation has been discussed for San Luis Potosi 
Table 5 Confusion matrix showing the agreement between field observations (columns) and the estimated data (rows)

\begin{tabular}{lcccccccc}
\hline & Very high & High & Moderate & Low & Very low & Total & User accuracy & Error of commission \\
\hline Very high & 1 & 0 & 0 & 0 & 0 & 1 & 1.0 & 0.0 \\
High & 0 & 1 & 0 & 0 & 0 & 1 & 1.0 & 0.0 \\
Moderate & 0 & 0 & 3 & 0 & 0 & 3 & 1.0 & 0.0 \\
Low & 0 & 0 & 0 & 5 & 0 & 5 & 1.0 & 0.0 \\
Very Low & 0 & 0 & 1 & 2 & 7 & 10 & 0.7 & 0.3 \\
Total & 1 & 1 & 4 & 7 & 7 & 20 & & \\
Producer accuracy & 1.0 & 1.0 & 0.8 & 0.7 & 1 & & & \\
Error of omission & 0.0 & 0.0 & 0.2 & 0.3 & 0.0 & & & \\
\hline
\end{tabular}

Global accuracy $\quad 85.0$

Kappa coefficient $\quad 0.84$

and other parts of the world (Miranda-Aragon et al., 2012; Sun et al., 2013) and, it corresponds with the observed in this study.

The temporal behavior of the average values of NDVI allows verifying a trend of relative stability characterized by a strong decrease of NDVI between 2000 and $2005(>0.1)$ followed by a slight recovery in the value of NDVI $(<-0.01$; Table $6 \mathrm{a})$. This result is explained regarding the character of vegetation that predominates in the area, and the deforestation processes related to the development of agriculture and grassland areas in Mexico (Díaz-Padilla et al., 2011; Miranda-Aragón et al., 2013), and in other continents (Helldén and Trttrup, 2008).

The average difference between the extreme values of $\mathrm{ST}$ is $5.86^{\circ} \mathrm{C}$. Comparing this result with the environmental temperature (ET) registered by the National Meteorological Service $\left(6.56^{\circ} \mathrm{C}\right.$ ), it can be seen that the behavior of both temperatures (ST vs. ET) is very similar (Figure 10b). Also, ST values obtained in this work from the thermal band of Landsat TM, are consistent with those reported by other studies carried out in arid and semi-arid zones (Sánchez et al., 2008; Tereshchenko et al., 2012). The results allow verifying that high ST variations are related to the El Niño and La Niña phenomena except the year 1990 which does not present an event of this kind (Null, 2013). Temperature difference analysis shows increases in almost all pairs of date, except for the pair 2000-2005 with a positive value of $8.9^{\circ} \mathrm{C}$, i.e., there is a significant decrease in temperature between these two dates. The weather station also reported this reduction in temperature. With this result, it is noted the fluctuations in temperature and not a constant increase of this one (Table 6e).

The results of the IO dynamics show variations in the content of the iron oxides among dates analyzed. A comparison between the values of IO and data of rainfall, suggests increases in IO when the precipitation values decrease (Figure 10c). In contrast, the comparison between the values of IO and ST draws a direct correlation between the two parameters (Figure 10d). Figure 7d shows the areas with the highest increase in IO located mainly in the west of the SLPP. Some of these regions have been previously reported as areas with alteration of oxidation - silicification derived from hydrothermal processes (Moreira-Rivera et al., 1996). 
Table 6 Average values obtained during each period analyzed for a) NDVI, b) ST, c) IO and d) NDWI. Subsection e) corresponds to the average value of the total balance for each factor

\begin{tabular}{|c|c|c|c|}
\hline a) Years & Minimum & Maximum & Average \\
\hline 1990-1995 & -0.59 & 0.63 & 0.01 \\
\hline $1995-2000$ & -0.61 & 0.58 & 0.02 \\
\hline 2000-2005 & -0.47 & 0.67 & 0.11 \\
\hline 2005-2011 & -0.62 & 0.52 & -0.01 \\
\hline b) Years & Minimum & Maximum & Average \\
\hline 1990-1995 & -14.63 & 14.34 & -1.93 \\
\hline 1995-2000 & -18.19 & 9.01 & -0.85 \\
\hline 2000-2005 & -13.26 & 18.7 & 8.90 \\
\hline 2005-2011 & -28.01 & -7.89 & -5.86 \\
\hline c) Years & Minimum & Maximum & Average \\
\hline 1990-1995 & -3.37 & 1.50 & -0.15 \\
\hline 1995-2000 & -1.63 & 2.75 & -0.04 \\
\hline 2000-2005 & -0.65 & 0.70 & 0.08 \\
\hline 2005-2011 & -1.5 & 0.63 & -0.1 \\
\hline d)Years & Minimum & Maximum & Average \\
\hline 1990-1995 & -1.03 & 1.94 & 0.51 \\
\hline $1995-2000$ & -1.38 & 1.16 & -0.06 \\
\hline 2000-2005 & -1.27 & 1.36 & 0.16 \\
\hline 2005-2011 & -1.28 & 1.08 & -0.14 \\
\hline
\end{tabular}

\begin{tabular}{lc}
\hline e) Variable & Average \\
\hline NDVI & 0.03 \\
ST & -3.77 \\
NDWI & 0.26 \\
IO & -0.07 \\
\hline
\end{tabular}

On the other hand, INEGI (2012) reported for this zone, soils with high concentrations of organic matter and iron oxides (Phaeozem and Kastanozem). The variability of iron oxides can be related to soil degradation processes as other works have suggested (Haboudane et al., 2002). Also, the desert varnish is an indicator of recent disturbances in the desert regions. Therefore, the IO values decrease can be related to the removal of the desert varnish (Spatz et al., 1989; Ustin et al., 2009). Then, in the study area, the fluctuations in the values of IO (Table 6c) suggest the removal of desert varnish in particular periods of time due to the growth of crop fields, the opening of roads and other types of activities such as mining. This kind of remark has also been registered in other regions of the world (Haboudane et al., 2002; Ustin et al., 2009).

By comparing the behavior of the NDWI with precipitation data from the National Weather Service (Figure 10e), it is observed a similar behavior between both parameters. From the observations of Gao (1996) and based on the results obtained for the region, it can be proposed that the average values of NDWI indicate the presence of soil with sparse vegetation and little moisture retention. This result is consistent with reports for other 


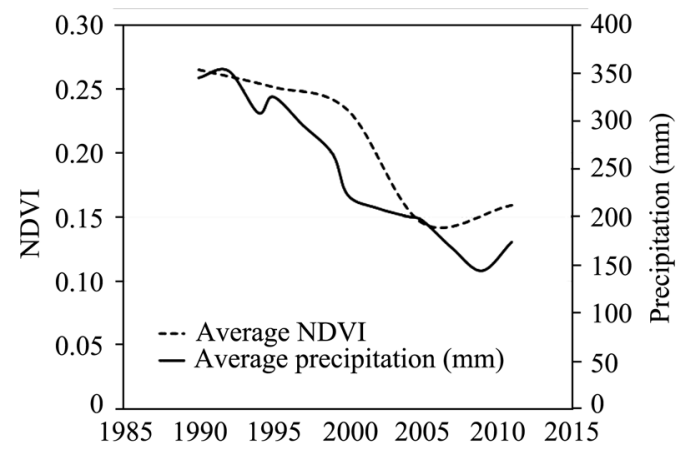

(a) Year

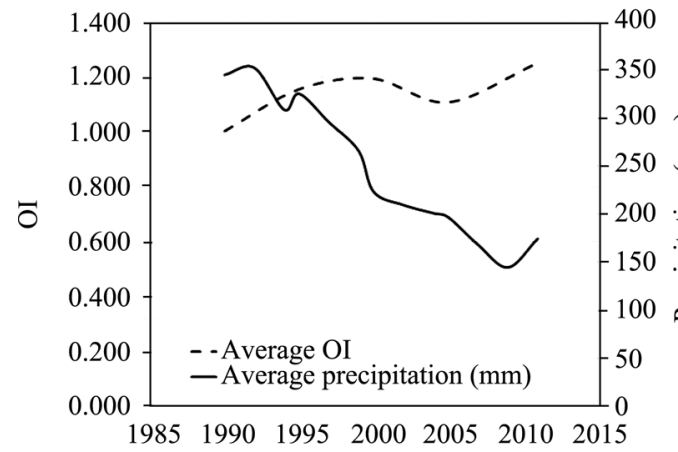

(c) Year

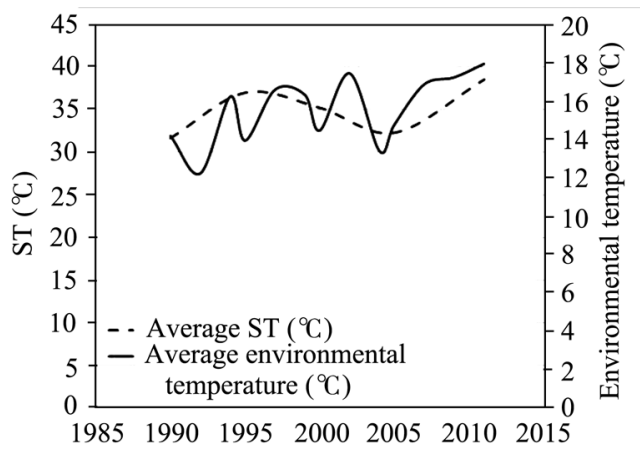

(b) Year

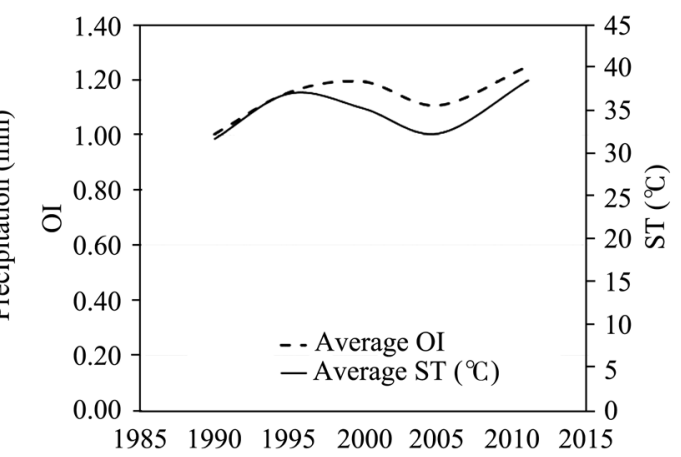

(d) Year

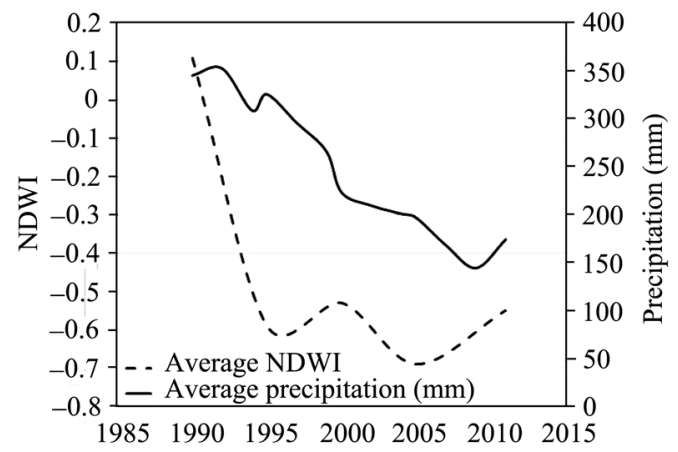

(e) Year

Figure 10 Comparison of the behavior of a) NDVI, b) ST, c) IO, and d) NDWI with precipitation or temperature obtained from the National Weather Service. The data of temperature and precipitation are the average of 15 days before the dates analyzed in this work. The standards were obtained based on information from 50 climatological stations.

semi-arid regions as the SLPP (Li et al., 2004; Wang et al., 2007; Xu et al., 2011). The analysis of pairs of dates (Table 6d) shows alternating periods of increases in NDWI (1995-2000 and 2005-2011), with cycles of decrements of this factor (1990-1995 and 2000-2005). These results demonstrate the fluctuations in moisture related to climatic oscillation phenomena (Figure 10e).

Table 6e shows the NDVI relatively stable from 1990 until 2011 (total balance $=0.03$ ), i.e., this parameter has preserved very similar values at the time, and its changes depend on the oscillations of the precipitation and temperature. NDWI presents an overall decrease reported by its average value $(0.26)$ which can be explained from the output of the total bal- 
ance of ST $\left(-3.77^{\circ} \mathrm{C}\right)$, suggesting a general increase in temperature, that's why the evaporation processes also increase. In the case of IO, the average value of the total balance $(-0.07)$ shows some stability of this factor over time analyzed.

The results of the susceptibility map show very high probability of developing desertification in a small zone of the region, which occupies an area of $1.2 \mathrm{~km}^{2}$ (Table 4). In contrast, the lowest probability of desertification occupies the largest surface of the area $\left(9154.67 \mathrm{~km}^{2}\right)$ followed by the category of low probability of desertification with an extension of 8637.56 $\mathrm{km}^{2}$. These results reveal cyclical changes in vegetation and moisture in the region. Hence, most of the study area don't have a high probability of developing desertification processes. The result is consistent with the work of Miranda-Aragón and others (2013) which point out that the SLPP does not have severe decreases in vegetation and the principal reductions are related to the scrub. In addition, Roth et al. (2016) indicate a low degree of human disturbing for this region of Mexico. This fact is an essential element in the processes of desertification as pointed out by other studies (Tao, 2004; Huber-Sannwald et al., 2006; Santini et al., 2010;. Becerril-Piña et al., 2015). The result also confirms the approach of the re-greening of vegetation and the development of cyclical phenomena, rather than an advance of desertification, as it has been observed in other regions of the world such as the Sahel (Dardel et al., 2014; Ouedraogo et al., 2014). The result obtained in this work is important to promote better arguments for decision-making processes for an adequate management of semi-arid areas.

\section{Conclusions}

This work focused on the analysis of Landsat TM images with the purpose of performing the temporary monitoring of the evolution of four factors (NDVI, ST, IO, and NDWI) to detect possible zones of developing desertification processes in the SLPP on the southern edge of the Chihuahuan Desert.

A clear trend for any of the factors analyzed are visible; rather they have a fluctuating behavior. Therefore, a new equation of total balance is proposed to hold the overall evolution of each factor.

The map of probability obtained in this study helped to corroborate that the most of the SLPP has a very low probability of developing desertification processes, and this category covers an area of $9154.67 \mathrm{~km}^{2}(37.34 \%)$. The next largest category corresponds to the low risk of desertification, which occupies an area of $8637.56 \mathrm{~km}^{2}(35.23 \%)$.

The results of this study confirm the approach of vegetation re-greening and the dynamics controlled by cyclical changes of climate typical of semi-desert zones. For that reason, only $8.8 \%$ of the study area requires more attention for its preservation and the rest of the region doesn't show significant advances of desertification. The municipalities with a greater probability of developing desertification processes are Santo Domingo, Villa de Ramos, Real de Catorce, Salinas de Hidalgo, and Charcas.

The methodology proposed in this paper proved to be useful to establish more concise settings to generate an adequate management plans for semi-desert zones.

\section{Acknowledgements}

This work has been financially supported by PRODEP through the financing program for 
new full-time professors, through the convention PROMEP/103.5/13/6575. The authors are grateful to MSci. Marco Antonio Rojas-Beltran by his determined support in the field verification and the capture of pictures of the study zone. We also wish to thank the corrections and suggestions from reviewers because their comments helped to improve this work.

\section{References}

Becerril-Piña R, Mastachi-Loza C A, González-Sosa E et al., 2015. Assessing desertification risk in the semi-arid highlands of central Mexico. Journal of Arid Environments, 120: 4-13. doi: 10.1016/j.jaridenv.2015.04.006.

Chander G, Markham B L, Helder D L, 2009. Summary of current radiometric calibration coefficients for Landsat MSS, TM, ETM+, and EO-1 ALI sensors. Remote Sensing of Environment, 113(5): 893-903. doi: 10.1016/j.rse.2009.01.007.

Collado D A, Chuvieco E, Camarasa A, 2002. Satellite remote sensing analysis to monitor desertification processes in the crop-rageland boundary of Argentina. Journal of Arid Environments, 52(1): 121-133. doi: 10.1006/jare.2001.0980.

Dardel C, Kergoat L, Hiernaux P et al., 2014. Re-greening Sahel: 30 years of remote sensing data and field observations (Mali, Niger). Remote Sensing of Environment, 140: 350-364. doi: 10.1016/j.rse.2013.09.011.

Díaz-Padilla G, Sánchez-Cohen I, Guajardo-Panes R A et al., 2011. Mapping of the aridity index and its populations distribution in Mexico. Revista Chapingo. Serie Ciencias Forestales y del Ambiente, 17(SPE): $267-275$. doi: 10.5154/r.rchscfa.2010.09.069.

De Waroux Y L P, Lambin E F, 2012. Monitoring degradation in arid and semi-arid forests and woodlands: The case of the argan woodlands (Morocco). Applied Geography, 32(2): 777-786. doi: 10.1016/j.apgeog.2011.08.005.

Dorn R I, 1986. Rock varnish as an indicator of aeolian environmental change. In: Nickling W G (ed.). Aeolian Geomorphology. Boston: Allen \& Unwin, p. 291-307.

Drury S, 1987. Image Interpretation in Geology. London: Allen and Unwin, p. 243.

Ezcurra E, 2006. Global Deserts Outlook. United Nations Environment Programme (UNEP): Nairobi, 148 p. http://www.unep.org/geo/gdoutlook/.

Galindo A S, García M E, 1986. Usos del mezquite (Prosopis L.) en el Altiplano Potosino. Agrociencia, 63: 7-16.

Gamo M, Shinoda M, Maeda T, 2013. Classification of arid lands, including soil degradation and irrigated areas, based on vegetation and aridity indices. International Journal of Remote Sensing, 34(19): 6701-6722. doi: 10.1080/01431161.2013.805281.

Gao B C, 1996. NDWI: A normalized difference water index for remote sensing of vegetation liquid water from space. Remote Sensing of Environment, 58(3): 257-266. doi: 10.1016/S0034-4257(96)00067-3.

Granados-Sánchez D, Hernández-García M Á, Vázquez-Alarcón A et al., 2013. The processes of desertification and arid regions. Revista Chapingo. Serie Ciencias Forestales y del Ambiente, 19(1): 45-66. doi: 10.5154/r.rchscfa.2011.10.077.

Haboudane D, Bonn F, Royer A et al., 2002. Land degradation and erosion risk mapping by fusion of spectrally-based information and digital geomorphometric attributes. International Journal of Remote Sensing, 23(18): 3795-3820. doi: 10.1080/01431160110104638.

Helldén U, 1992. Desertification: Time for an assessment. Ambio, 20: 372-383. http://www.jstor.org/stable/4313868.

Helldén U, Tottrup C, 2008. Regional desertification: A global synthesis. Global and Planetary Change, 64(3/4): 169-176. doi: 10.1016/j.gloplacha.2008.10.006.

Hernández H M, Gómez-Hinostrosa C, Bárcenas R T, 2001. Diversity, spatial arrangement, and endemism of Cactaceae in the Huizache area, a hot-spot in the Chihuahuan Desert. Biodiversity \& Conservation, 10(7): 1097-1112. doi: 10.1023/A:1016606216041.

Huber-Sannwald E, Maestre F T, Herrick J E et al., 2006. Ecohydrological feedbacks and linkages associated with land degradation: A case study from Mexico. Hydrological Processes, 20(15): 3395-3411. doi: 10.1002/hyp.6337.

Huete A R, Didan K, Miura T et al., 2002. Overview of the radiometric and biophysicial performance of the MODIS Vegetation Indices. Remote Sensing of Environment, 83: 195-213. doi: 10.1016/S0034-4257(02) 00096-2.

INEGI, 2012. Anuario de estadísticas por entidad federativa. Aguascalientes, México. Available at: http: //www.inegi.org.mx/prod_serv/contenidos/espanol/bvinegi/productos/integracion/pais/aepef/2012/aepef2012.p 
df. Accessed 15 August 2013.

Li H, Wang X F, Gao Y Q, 2004. Analysis and assessment of land desertification in Xinjiang based on RS and GIS. Journal of Geographical Sciences, 14(2): 159-166. doi: 10.1007/BF02837531.

Miranda-Aragón L, Treviño-Garza E J, Jiménez-Pérez J et al., 2012. NDVI-rainfall relationship using hyper-temporal satellite data in a portion of North Central Mexico (2000-2010). African Journal of Agricultural Research, 7(6): 1023-1033. doi: 10.5897/AJAR11.1674.

Miranda-Aragón L, Treviño-Garza E J, Jiménez-Pérez J et al., 2013. Tasa de deforestación en San Luis Potosí, México (1993-2007). Revista Chapingo. Serie Ciencias Forestales y del Ambiente, 19(2): 201-215. doi: 10.5154/r.rchscfa.2011.06.044.

Moreira-Rivera F, Martínez-Rodríguez L, Palacios-García R et al., 1996. Carta Geológico-Minera Matehuala (F14-1). 1a edición. Servicio Geológico Mexicano, Pachuca, Hidalgo, México.

Null J, 2013. El Niño and La Niña years and intensities. Available at http://ggweather.com/enso/oni.htm. Accessed 20 September 2013.

Ouedraogo I, Runge J, Eisenberg J et al., 2014. The re-greening of the Sahel: Natural cyclicity or human-induced change? Land, 3(3): 1075-1090. doi: 10.3390/land3031075.

Oyama M D, Nobre C A, 2004. Climatic consequences of a large-scale desertification in Northeast Brazil: A GCM simulation study. Journal of Climate, 17(16): 3203-3213. doi: 10.1175/1520-0442(2004)017<3203: CCOALD>2.0.CO;2.

Pando-Moreno M, Gutiérrez G, Maldonado H et al., 2002. Evaluación de los procesos de desertificación en una cuenca hidrológica del NE de México. Ciencia UANL, 5(4): 519-524. http://eprints.uanl.mx/id/eprint/1166.

Reynolds J F, Smith D M S, Lambin E F et al., 2007. Global desertification: Building a science for dryland development. Science, 316(5826): 847-851. doi: 10.1126/science.1131634.

Roth D, Moreno-Sanchez R, Torres-Rojo J M et al., 2016. Estimation of human induced disturbance of the environment associated with 2002, 2008 and 2013 land use/cover patterns in Mexico. Applied Geography, 66: 22-34. doi: 10.1016/j.apgeog.2015.11.009.

Sánchez J M, Kustas W P, Caselles V et al., 2008. Modelling surface energy fluxes over maize using a two-source patch model and radiometric soil and canopy temperature observations. Remote Sensing of Environment, 112(3): 1130-1143. doi: 10.1016/j.rse.2007.07.018.

Santini M, Caccamo G, Laurenti A et al., 2010. A multi-component GIS framework for desertification risk assessment by an integrated index. Applied Geography, 30(3): 394-415. doi: 10.1016/j.apgeog.2009.11.003.

Spatz D M, Taranik J V, Hsu L C, 1989. Differetiating volcanic rock assemblages using Landsat Thematic Mapper data-Influence of petrochemistry and desert varnish. Advances in Space Research, 9(1): 93-98. doi: 10.1016/0273-1177(89)90472-9.

Sun W, Shao Q, Liu J, 2013. Soil erosion and its response to the changes of precipitation and vegetation cover on the Loess Plateau. Journal of Geographical Sciences, 23(6): 1091-1106. doi: 10.1007/s11442-013-1065-z.

Tao W, 2004. Progress in sandy desertification research of China. Journal of Geographical Sciences, 14(4): 387-400. doi: 10.1007/BF02837482.

Tereshchenko I, Zolotokrylin A N, Titkova T B et al., 2012. Seasonal variation of surface temperature-modulating factors in the Sonoran Desert in northwestern Mexico. Journal of Applied Meteorology and Climatology, 51(8): 1519-1530. doi: 10.1175/JAMC-D-11-0160.1.

Tucker C J, Dregne H E, Newcombe W W, 1991. Expansion and contraction of the Sahara desert from 1980 to 1990. Science, 253: 299-301. doi: 10.1126/science.253.5017.299.

USDA-NRCS, 1998. Estimating soil moisture by feel and appearance. Program Aid No.1619. USDA-NRCS, Washington, DC.

Ustin S L, Palacios-Orueta A, Whiting M L et al., 2009. Remote sensing based assessment of biophysical indicators for land degradation and desertification. In: Röder A, Hill J (eds.). Tecent Advances in Remote Sensing and Geoinformation Processing for Land Degradation Assessment. London: CRC Press, 15-44

$\mathrm{Xu}$ D, Li C, Zhuang D et al., 2011. Assessment of the relative role of climate change and human activities in desertification: A review. Journal of Geographical Sciences, 21(5): 926-936. doi: 10.1007/s11442-011-0890-1. 